\title{
Assessing the Impact of the ECB's Monetary Policy on the Stock Markets: A Sectoral View
}

\section{Working Paper}

\section{Author(s):}

Kholodilin, Konstantin A.; Montagnoli, Alberto; Siliverstovs, Boriss; Napolitano, Oreste

Publication date:

2008-12

Permanent link:

https://doi.org/10.3929/ethz-a-005717936

\section{Rights / license:}

In Copyright - Non-Commercial Use Permitted

Originally published in:

KOF Working Papers 213 


\section{KOF Working Papers}

Assessing the Impact of the ECB's Monetary Policy on the Stock Markets: A Sectoral View

Konstantin Kholodilin, Alberto Montagnoli, Oreste Napolitano, and Boriss Siliverstovs 


\section{KOF}

ETH Zurich

KOF Swiss Economic Institute WEH D 4

Weinbergstrasse 35

8092 Zurich

Switzerland

Phone +41446324239

Fax +4144 6321218

www.kof.ethz.ch

kof@kof.ethz.ch 


\title{
Assessing the impact of the ECB's monetary policy on the stock markets: A sectoral view**
}

\author{
Konstantin Kholodilin ${ }^{\S} \quad$ Alberto Montagnoli $₫$ \\ Oreste Napolitano" Boriss Siliverstovs*
}

December 7, 2008

\begin{abstract}
This paper analyzes the response of the European stock markets to the monetary policy shocks by the European Central Bank using the heteroskedasticity based approach of Rigobon (2003). We find that monetary policy tightening has a heterogeneous impact on the Euro Area sectors on the day the monetary policy is publicly announced. Furthermore, we provide statistical evidence against the use of the popular event study approach when assessing the impact of monetary policy shocks on the stock market as the maintained assumptions can be rejected for the aggregate stock market and for most of the sectoral stock market indexes.
\end{abstract}

Keywords: Monetary policy, Stock markets, ECB

JEL code: E44, E47, E52.

${ }^{* *}$ The paper has benefited from comments made by participants at the DIW Macroeconometric Workshop, Berlin, Germany.

${ }^{\S}$ DIW Berlin, Mohrenstraße 58, 10117 Berlin, Germany, e-mail: kkholodilin@diw.de

IUniversity of Stirling, Stirling, FK9 4LA, UK, e-mail: alberto.montagnoli@stir.ac.uk

"Parthenope University of Naples, via Medina 40, 80133 I - Napoli, e-mail: napolitano@uniparthenope.it

*ETH Zurich, KOF Swiss Economic Institute, Weinbergstrasse 35, 8092 Zurich, Switzerland, e-mail: boriss.siliverstovs@kof .ethz.ch, corresponding author 


\section{Introduction}

In recent years a growing number of studies have provided evidence on the relationship between monetary policy and the stock market. Most of the studies focus on the real effects of monetary policy on the US stock market(e.g, Patelis, 1997; Conover, Jensen, and Johnson, 1999; Bomfim, 2003; Ehrmann and Fratzscher, 2004; Rigobon and Sack, 2004, among others). In contrast, Bohl, Siklos, and Sondermann (2007) is the only study known to us that analyses the impact of the ECB's policy on national stock markets of four major countries in Europe. Our paper complements the study of Bohl et al. (2007) by assessing the impact of monetary policy of the ECB on the stock returns using the industry specific rather than the national market dimension.

We employ the heteroskedasticity based approach of Rigobon (2003) and Rigobon and Sack (2004) which we compare with a more widely applied event study method. We find that the ECB's monetary policy instrument does have a negative and statistically significant influence on the stock markets in the Euro area. More importantly, we show that the assumptions behind the event study estimator are violated in our data and we find evidence against the use of this estimator for the data at hand. At the same time, we find no deviations from model assumptions implied by the heteroskedasticity based approach.

The paper is structured as follows. The next section presents the formal model. Section 3 describes the data and the estimation results. The final section concludes.

\section{Empirical Specifications}

The econometric model is given by:

$$
\begin{aligned}
\Delta i_{t} & =\beta \Delta s_{t}+\gamma z_{t}+\varepsilon_{t} \\
\Delta s_{t} & =\alpha \Delta i_{t}+z_{t}+\eta_{t}
\end{aligned}
$$

where $\Delta i_{t}$ and $\Delta s_{t}$ are changes in the interest rate and the stock market returns, $z_{t}$ is a vector of other (exogenous) variables that affect both the interest rate and the stock market returns.

The coefficient of interest is $\alpha$, which measures (negative) reaction of stock market to the 
monetary policy instrument. Direct estimation of the parameter $\alpha$ is not straightforward as both the short-run interest rate and the asset returns are jointly determined. There are also a number of other variables that influence both the interest rate and asset prices.

We apply the approach suggested in Rigobon and Sack (2004) which allows us to overcome these two problems. It is based on the assumption that the variance of the monetary policy shocks is higher on days when a policy decision is announced compared to that observed on the non-policy dates. Rigobon and Sack (2004) show that the observed heteroskedasticity of monetary policy shocks is a sufficient condition to measure the responsiveness of asset prices to monetary policy shocks. To see this, express the simultaneous equations (1) and (2) in the reduced form and define the corresponding covariance matrices $\Omega_{F}=E\left[\left[\Delta i_{t} \Delta s_{t}\right]^{\prime}\right.$. $\left.\left[\Delta i_{t} \Delta s_{t}\right] \mid t \in F\right]$ and $\Omega_{F^{*}}=E\left[\left[\Delta i_{t} \Delta s_{t}\right]^{\prime} \cdot\left[\Delta i_{t} \Delta s_{t}\right] \mid t \in F^{*}\right]$ for the subsamples for the 'policy' and 'no-policy' dates, respectively. Then assuming that the parameters $\alpha, \beta$ and $\gamma$ are stable across subsamples and the following condition among the second moments hold

$$
\begin{aligned}
\sigma_{\varepsilon}^{F} & >\sigma_{\varepsilon}^{F^{*}} \\
\sigma_{\eta}^{F} & =\sigma_{\eta}^{F^{*}} \\
\sigma_{z}^{F} & =\sigma_{z}^{F^{*}}
\end{aligned}
$$

the shift in the covariance structure between the policy and non-policy dates is

$$
\Delta \Omega=\Omega_{F}-\Omega_{F^{*}}=\lambda\left[\begin{array}{cc}
1 & \alpha \\
\alpha & \alpha^{2}
\end{array}\right]
$$

where $\lambda=\frac{\sigma_{\varepsilon}^{F}-\sigma_{\varepsilon}^{F^{*}}}{(1-\alpha \beta)^{2}}$ is the parameter that measures the degree of heteroskedasticity in the data. Then the parameter $\alpha$ can be recovered either by means of instrumental variables (IV) or by generalised method of moments (GMM). We will compare the estimates obtained by these two methods with the more popular event study (ES) approach, which is based on ordinary least squares regression. The assumption underlying the event study approach is that the variance of the monetary policy shock is infinitely large relative to the variances of the other shocks, i.e., $\sigma_{\varepsilon} / \sigma_{z} \rightarrow \infty$ and $\sigma_{\varepsilon} / \sigma_{\eta} \rightarrow \infty$. The validity of these assumptions can be tested using the Hausman-type test (see Rigobon and Sack, 2004). 


\section{Results}

We focus on the effect of monetary policy on aggregate as well as on ten sectoral stock market indexes for the whole Euro area classified according to the ICB Industry. Following Bohl et al. (2007), we employ the 1-month EURIBOR interest rate as the proxy for monetary policy shocks. ${ }^{1}$ Both the interest rate changes $\Delta i_{t}$ and the stock market returns $\Delta s_{t}$ are expressed in percentage points.

The sample runs from January 1999 till January 2008, providing us with 140 meetings of the Governing Council of the ECB, which are assumed to be the policy dates. Due to the fact that the EURIBOR is published at 11 a.m. Central European Time (C.E.T.) every weekday, i.e., before the decision of the Governing Council is announced at 1.45 p.m. C.E.T., we use the quotes of the days following the meeting for our policy dates. The stock market returns are calculated using the closing prices at the same day the meeting of the Governing Council takes place. The non-policy dates are defined as the days preceding the policy dates.

We do not attempt here to separate days when monetary policy changes constituted a surprise and the days when they do not. There is a substantial degree of arbitrariness involved in deciding whether the policy surprises occur or not. For example, Bohl et al. (2007) present the three different ways of determining the surprise shocks and this leads to three partly overlapping sets of dates. Moreover, we experimented with dates of surprise shocks provided in Bohl et al. (2007) and, additionally, by omitting the days when changes in the interest rates were below a certain threshold, and we find that our conclusions are robust to such changes in the sample size.

Table 1 contains some descriptive statistics on daily changes in the interest rate and the stock market returns on policy and non-policy dates. The first thing to notice is that the variance of changes in the short-term interest rate is much higher on policy dates than that on non-policy dates. In fact, the corresponding standard deviation is about three times larger on policy rather than on non-policy dates because of a higher variance of shocks occurring at the policy dates. At the same time, the difference in standard deviations of the stock market returns on policy and non-policy dates is much smaller implying that the homoskedasticity assumption of shocks to asset price equation is likely not to be violated in our sample. The second thing to observe is that there is a definite and substantial change in the covariance

\footnotetext{
${ }^{1}$ All data are from Datastream.
} 
between the interest rate and asset returns observed on the policy vs non-policy dates. The covariance is negative on policy dates for all sectors and it is substantially larger (in the absolute value) than that observed on non-policy dates. As explained above, such shift in the covariance between these variables ensures that the system of simultaneous equations is identified and therefore the parameter of interest $\alpha$, measuring the impact of monetary policy on stock markets, can be estimated.

Table 2 presents estimation results for the two heteroskedasticity based estimators as well as for the event study estimator. Both the IV and the GMM estimates of the parameter $\alpha$ for total stock market returns are negative and significantly different from zero suggesting that an increase in interest rate by 25 basis points results in about a $1 \%$ drop in the aggregate stock market index on the same day when the monetary policy decision is announced. Interestingly this response is similar in magnitude to the response of the Dow Jones Industrial Average to FFR found by Rigobon and Sack (2004). Looking at the sectoral indexes, the GMM estimates are all negative and in seven of the ten cases they are statistically significant. More specifically, a monetary policy tightening of 25 basis points produces a heterogeneous response across sectors, which varies from the $0.3 \%$ of the Consumption Servises sector to the $2 \%$ decrease of the Telecommunication sector.

Comparison of the estimates of the heteroskedasticity based approach with those of the event study approach reveals that the latter estimates are much smaller than the former. For example, for the total stock market index it is only as small as half of the IV or GMM estimate.

The specification tests for the GMM estimator reveal no signs of deviations from model assumptions. The estimate of the parameter $\lambda$ that measures the degree of heteroskedasticity present in the data is significant at the $5 \%$ level. This implies that the variance of the policy shocks shifts across the policy and the non-policy dates. Furthermore, the test for overidentifying restrictions implied by the GMM estimator is never significant at the usual levels suggesting that the null hypothesis that maintained moment conditions are statistically valid cannot be rejected. In contrast, the Hausman test statistic obtained by comparing the event study estimates versus the GMM estimates is significant for the aggregate stock market index as well as for the six sectors suggesting that the assumptions behind the event study are violated and hence the event study estimator is (downwards) biased. 


\section{Conclusion}

This paper investigates the impact of the ECB's monetary policy on the aggregate and sectoral European stock market indexes. We found that, depending on the sectors, an increase in the interest rate by 25 basis points results in a decrease in stock market in the range between $0.3 \%$ and $2.0 \%$ on the day the monetary policy shock is publically announced. At the aggregate stock market level, the corresponding decrease approximately constitutes $1.0 \%$. We assessed the impact of monetary policy using the heteroskedasticity based approach of Rigobon (2003) as well as the more popular event study methodology. We found that the estimates obtained by the latter methods are downwards biased and, more importantly, we showed evidence against the main assumptions on which the event study approach is based. These results suggest that care should be exercised whenever the event study approach is employed and its underlying statistical assumptions should be tested. 


\section{References}

Bohl, M. T., P. L. Siklos, and D. Sondermann (2007). Shocking markets: European stock markets and the ECB's monetary policy surprises. Available at SSRN: http://ssrn.com/abstract=1091133.

Bomfim, A. N. (2003). Pre-announcement effects, news effects, and volatility: Monetary policy and the stock market. Journal of Banking \&6 Finance 27(1), 133-151.

Conover, C. M., G. R. Jensen, and R. R. Johnson (1999). Monetary environments and international stock returns. Journal of Banking E Finance 23(9), 1357-1381.

Ehrmann, M. and M. Fratzscher (2004). Taking stock: Monetary policy transmission to equity markets. Working Paper Series 354, European Central Bank.

Patelis, A. D. (1997). Stock return predictability and the role of monetary policy. Journal of Finance 52(5), 1951-72.

Rigobon, R. (2003). Identification through heteroskedasticity. The Review of Economics and Statistics 85(4), 777-792.

Rigobon, R. and B. Sack (2004). The impact of monetary policy on asset prices. Journal of Monetary Economics 51(8), 1553-1575. 
Table 1: Variances, covariances and correlations on policy and non-policy dates

\begin{tabular}{|c|c|c|c|c|c|c|}
\hline & \multicolumn{2}{|c|}{ Std. dev. of asset prices } & \multicolumn{4}{|c|}{ Covariance (correlation) with policy rate } \\
\hline & $\mathrm{F}$ dates & $\mathrm{F}^{*}$ dates & & ates & & $\mathrm{F}^{*}$ dates \\
\hline Policy rate & 5.816 & 1.910 & - & - & - & - \\
\hline Oil and gas (OILGSEM) & 1.462 & 1.337 & -0.991 & $(-0.116)$ & 0.294 & $(0.115)$ \\
\hline Building materials (BMATREM) & 1.083 & 1.022 & -0.216 & $(-0.034)$ & 0.176 & $(0.090)$ \\
\hline Industrial (INDUSEM) & 1.398 & 1.334 & -0.722 & $(-0.089)$ & 0.263 & $(0.103)$ \\
\hline Consumption goods (CNSMGEM) & 1.274 & 1.288 & -1.368 & $(-0.185)$ & 0.306 & $(0.124)$ \\
\hline Health care (HLTHCEM) & 1.132 & 0.915 & -1.112 & $(-0.169)$ & 0.191 & $(0.110)$ \\
\hline Consumption services (CNSMSEM) & 1.179 & 1.344 & -0.699 & $(-0.102)$ & 0.249 & $(0.097)$ \\
\hline Telecommunications (TELCMEM) & 2.144 & 1.782 & -2.185 & $(-0.175)$ & 0.240 & $(0.071)$ \\
\hline Utility (UTILSEM) & 1.015 & 0.940 & -0.448 & $(-0.076)$ & 0.064 & $(0.036)$ \\
\hline Financial (FINANEM) & 1.179 & 1.020 & -1.173 & $(-0.171)$ & 0.107 & $(0.055)$ \\
\hline Technology (TECNOEM) & 2.957 & 2.435 & -0.507 & $(-0.030)$ & 0.760 & $(0.163)$ \\
\hline Total (TOTMKEM) & 1.182 & 1.094 & -1.002 & $(-0.146)$ & 0.245 & $(0.118)$ \\
\hline
\end{tabular}


Table 2: The impact of monetary policy on stock prices

\begin{tabular}{|c|c|c|c|c|c|c|c|}
\hline & \multirow[t]{2}{*}{$\widehat{\alpha}_{h e t}^{I V}$} & \multirow[t]{2}{*}{$\widehat{\alpha}_{E S}$} & \multirow[t]{2}{*}{$\widehat{\alpha}_{h e t}^{G M M}$} & \multirow[t]{2}{*}{$\widehat{\lambda}_{\text {het }}^{G M M}$} & \multirow[t]{2}{*}{ Test of O.I. ${ }^{a}$} & \multicolumn{2}{|c|}{ Test of E.S. rest. ${ }^{b}$} \\
\hline & & & & & & ES vs IV & ES vs GMM \\
\hline Oil and gas (OILGSEM) & $\begin{array}{c}-0.0426^{* c} \\
(0.024)\end{array}$ & $\begin{array}{c}-0.0186 \\
(0.014)\end{array}$ & $\begin{array}{c}-0.0446^{* *} \\
(0.019)\end{array}$ & $\begin{array}{c}29.7704^{* *} \\
(14.264)\end{array}$ & {$[0.514]$} & {$[0.218]$} & {$[0.031]$} \\
\hline Building materials (BMATREM) & $\begin{array}{r}-0.0130 \\
(0.018)\end{array}$ & $\begin{array}{l}-0.0011 \\
(0.012)\end{array}$ & $\begin{array}{r}-0.0136 \\
(0.018)\end{array}$ & $\begin{array}{c}29.7315^{* *} \\
(14.244)\end{array}$ & {$[0.651]$} & {$[0.377]$} & {$[0.333]$} \\
\hline Industrial (INDUSEM) & $\begin{array}{l}-0.0326 \\
(0.024)\end{array}$ & $\begin{array}{r}-0.0122 \\
(0.016)\end{array}$ & $\begin{array}{c}-0.0340^{*} \\
(0.019)\end{array}$ & $\begin{array}{c}29.9445^{* *} \\
(14.260)\end{array}$ & {$[0.741]$} & {$[0.235]$} & {$[0.021]$} \\
\hline Consumption goods (CNSMGEM) & $\begin{array}{c}-0.0555^{* *} \\
(0.022)\end{array}$ & $\begin{array}{c}-0.0283^{* *} \\
(0.014)\end{array}$ & $\begin{array}{c}-0.0539^{* * *} \\
(0.021)\end{array}$ & $\begin{array}{c}30.5267^{* *} \\
(14.238)\end{array}$ & {$[0.750]$} & {$[0.106]$} & {$[0.085]$} \\
\hline Health care (HLTHCEM) & $\begin{array}{c}-0.0432^{* *} \\
(0.018)\end{array}$ & $\begin{array}{c}-0.0246^{* * *} \\
(0.010)\end{array}$ & $\begin{array}{c}-0.0441^{* * *} \\
(0.014)\end{array}$ & $\begin{array}{c}29.4591^{* *} \\
(14.269)\end{array}$ & {$[0.147]$} & {$[0.212]$} & {$[0.066]$} \\
\hline Consumption services (CNSMSEM) & $\begin{array}{l}-0.0314 \\
(0.022)\end{array}$ & $\begin{array}{l}-0.012 \\
(0.012)\end{array}$ & $\begin{array}{c}-0.0268^{* *} \\
(0.013)\end{array}$ & $\begin{array}{c}30.7168^{* *} \\
(14.268)\end{array}$ & {$[0.313]$} & {$[0.279]$} & {$[0.003]$} \\
\hline Telecommunications (TELCMEM) & $\begin{array}{c}-0.0804^{* *} \\
(0.034)\end{array}$ & $\begin{array}{c}-0.0519^{* *} \\
(0.023)\end{array}$ & $\begin{array}{c}-0.0803^{* * *} \\
(0.025)\end{array}$ & $\begin{array}{c}29.7132^{* *} \\
(14.272)\end{array}$ & {$[0.235]$} & {$[0.249]$} & {$[0.002]$} \\
\hline Utility (UTILSEM) & $\begin{array}{r}-0.0170 \\
(0.017)\end{array}$ & $\begin{array}{c}-0.0102 \\
(0.010)\end{array}$ & $\begin{array}{r}-0.0173 \\
(0.015)\end{array}$ & $\begin{array}{c}29.6400^{* *} \\
(14.254)\end{array}$ & {$[0.516]$} & {$[0.610]$} & {$[0.499]$} \\
\hline Financial (FINANEM) & $\begin{array}{c}-0.0424^{* *} \\
(0.019)\end{array}$ & $\begin{array}{c}-0.0284^{*} \\
(0.013)\end{array}$ & $\begin{array}{c}-0.0453^{* *} \\
(0.018)\end{array}$ & $\begin{array}{c}29.3756^{* *} \\
(14.254)\end{array}$ & {$[0.330]$} & {$[0.320]$} & {$[0.187]$} \\
\hline Technology (TECNOEM) & $\begin{array}{r}-0.0420 \\
(0.047)\end{array}$ & $\begin{array}{l}0.0067 \\
(0.040)\end{array}$ & $\begin{array}{r}-0.0545 \\
(0.040)\end{array}$ & $\begin{array}{c}29.1875^{* *} \\
(14.264)\end{array}$ & {$[0.117]$} & {$[0.042]$} & na \\
\hline Total (TOTMKEM) & $\begin{array}{c}-0.0413^{* *} \\
(0.020)\end{array}$ & $\begin{array}{c}-0.0202^{*} \\
(0.011)\end{array}$ & $\begin{array}{c}-0.0434^{* * *} \\
(0.014)\end{array}$ & $\begin{array}{c}29.8826^{* *} \\
(14.266)\end{array}$ & {$[0.610]$} & {$[0.185]$} & {$[0.004]$} \\
\hline
\end{tabular}

$a-$ GMM test for overidentifying restrictions, p-value are reported in square brackets.

$b$ - Hausman test for validity of the underlying assumptions of the event study (ES) estimator, tested against the IV and the GMM estimators.

$c_{-}{ }^{*} * * *,{ }^{*} * *$, and ${ }^{*}$ ', denote the significance at the $1 \%, 5 \%$ and $10 \%$ levels, respectively. The corresponding standard errors are reported in parentheses below the parameter estimates. 